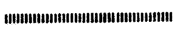 技術報告＼cjkstart極低温疲れ試験装置の概要と運転状況

\author{
緒形 俊夫*·石川 圭介*2 - 長井 寿*2 \\ 平賀啓二郎* ·中曾根祐司 ${ }^{* 2} \cdot$ 由利，哲美*
}

\section{Helium Cooling System for Long-term Fatigue Test at Liquid Helium Temperature}

\author{
Toshio Ogata, Keisuke Ishikawa, Kotobu NAgAI, \\ Keijiro HIRAgA, Yuji NAKAsone and Tetsumi YURI
}

\begin{abstract}
Synopsis :
A Fatigue Testing Machine at Liquid Helium Temperature with new re-condensing type cooling system was installed in National Research Institute for Metals, Tsukuba Laboratories. The machine has been designed for long-term fatigue testing at liquid helium temperature. The machine has a recondenser in the closed test machine cryostat. Helium mist is transferred to the recondenser from the refrigerator and evaporated helium gas is recondensed in the cryostat. The liquid helium level in the cryostat is kept constant without additional supply of liquid helium during the testing. This recondensing type cooling system has achieved long-term continuous operation for more than $460 \mathrm{~h}$.
\end{abstract}

\section{1. 緒}

言

極低温における超電導現象利用技術の進歩に伴い，液 体へリウム温度 $\left(-269^{\circ} \mathrm{C}\right)$ でも十分信頼性の高い構造 材料が求められている. 強度・鞇性のデータとともに構 造材料の信頼性を確認しから材料開発の目安として, 疲 れ強度データが不可欠である. 昭和 58 年 3 月, 「極低温 疲れ試験装置」が金属材料技術研究所筑波支所以設置さ れた. 以来, 本装置は順調に稼動し, 各種構造材料の極 低温に拊ける繰り返し応力による疲れ寿命を予測するた めの試験を行つている.

液体へリウム温度における材料の疲れ試験データの蓄 積の必要性にもかかわらず，現在に至るまで十分に行わ れていない. 主な報告として， 米国の NBS (National Bereau of Standards) の報告1)が唯一である。これは極 低温における疲れ試験が難しいためである. 疲れ寿命を 予測するには破断繰り返し回数 $\left(N_{f}\right)$ が $10^{6}$ 程度の長 時間の試験データが必要である. 疲れ破壊の特徵として $N_{f}$ の予測は難しく, 途中で試験を中断することはでき ない.さらに極低温では金属材料の比熱括よび熱伝導率 はそれぞれ常温の 1000 分の 1 および 10 分の 1 程度に なり2)，わずかの変形によつて発熱しやすく試験片の温 度が上昇してしまうため, 試験周波数を高めて試験時間
を短縮することも不可能である．以上のことから極低温 において疲れ試験を行らためには, 試験片の内部発熱と 外部からの熱侵入を除去する安定した長時間冷却システ ムが必要となる.

液体へリウム温度において疲れ試験を行らための冷却 方法として, 試験片を液体へリウムに浸漬し必要に応じ て蒸発した液体へリウムを補給する方法と，蒸発したへ リウムガスを回収し液化機により再液化する方法があ る. 液体へリウムをつぎ足す方法は最も簡単であるが長 時間にわたつて補給し続けることは, 高価な液体へリウ ムの消費量が增大寸るとともに補給のための労力が絶兄 ず必要とされる．次に蒸発したがスを回収し再液化する 装置を設ける方法では液体へリウム消費量および労力は 削減されるが，ガスを回収する際に水分や空気成分等の 不純物の混入の可能性が大きく，ガス精製機の運転を伴 らヘリウム液化機の長時間連続運転は難しく保守子繁雑 となる.

本装置では不純物の混入を極力回避しへリウム冷凍機 の長時間連続運転を可能にするため, ヘリウムの閉ルー プ再凝縮方式を世界で初めて採用し実用化した. 現在ま で，再凝縮冷凍装置の 1 回の連続運転としては， $460 \mathrm{~h}$ 以上の実績を得ている. 昭和 59 年 4 月本会講演大会にて発表 昭和 59 年 7 月 30 日受付 (Received July 30， 1984)

* 金属材料技術研究所筑波支所 (Tsukuba Laboratories, National Research Institute for Metals, 1-2-1 Sengen Sakuramura Niihari-gun Ibaraki pref. 305)

*2 金属材料技術研究所筑波支所工博 (Tsukuba Laboratories, National Research Institute for Metals) 


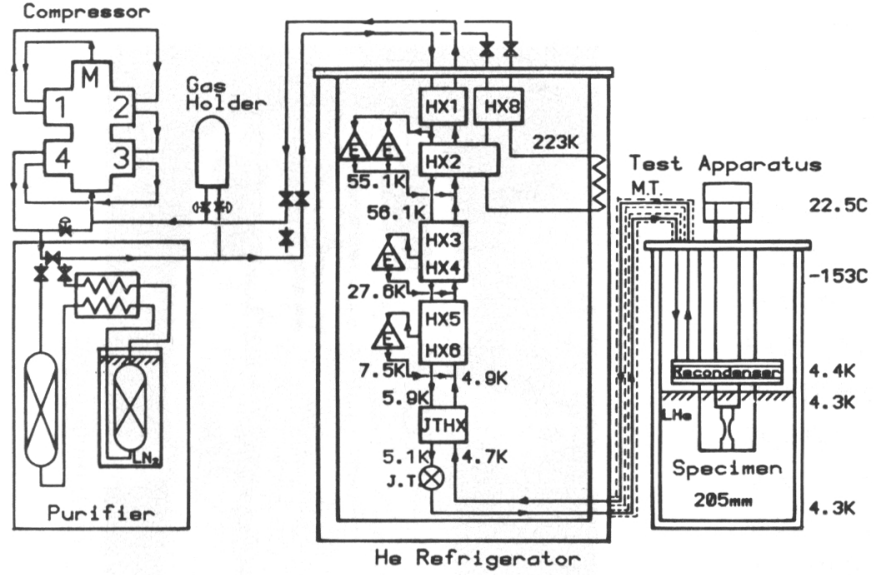

Fig. 1. Flow diagram of fatigue testing machine at liquid helium temperature.

$\mathrm{HX}$ : heat exchanger,

J.T. : Joule-Thomson valve

$\mathrm{E}$ : expander engine,

M.T. : mist transfer tube

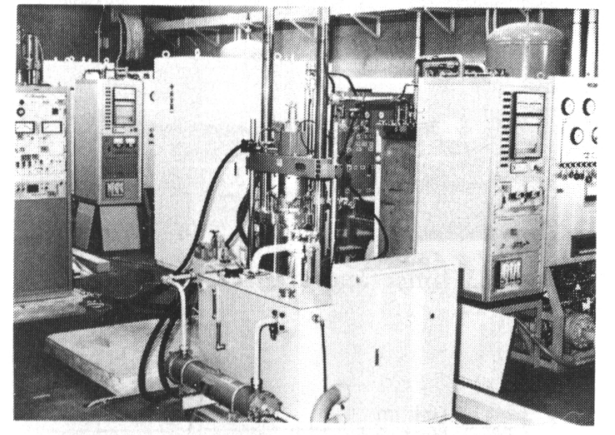

Photo. 1. Whole view of fatigue testing machine at liquid helium temperature.

\section{2. ヘリゥム冷却システムおよび疲れ試験機}

\section{$2 \cdot 1$ 装置の構成}

本装置はへリウムガスを送り出すための圧縮機, あら かじめガス中の不純物を除去するための機外精製機, 精 製したガスを蓄え閉ループ内のガス量を調整するガスホ ルダ，ガスを冷却しへリウムミストを生成する冷凍機と 疲れ試験機から成る. Photo. 1 は本装置の概観である (ただし圧縮機は別室にある). 本装置の冷却システムに おけるへリウムガスの流れのプロセスを Fig. 1 に示 す. 図中の数字は疲れ試験を行つている定常状態での, 各部の温度の一例である.

本装置の泠却系統は二つに分けられる. 一つは冷凍機 内のジュール・トムソン (以下 JT と称する) 弁によつ て作られたヘリウムミストを, 寒冷として試験機クライ オスタット内の再凝縮器に送る閉ループであり, もう一 つは密閉されたクライオスタット内での蒸発したへリウ ムガスを再凝縮するループである。

\section{$2 \cdot 2$ ヘリウム圧縮機}

圧縮機により冷凍機の膨張エンジン入口および JT 弁 入口までの高圧側のへリウムガスの圧力は, 約 $16 \mathrm{~atm}$ (1.7 MPa) まで昇圧される. 圧縮機の型式は水平対向 無潤滑往復動 4 段型で, 完全密閉型である. 閉ループ内 への油や空気成分等の不純物の混入を長時間にわたつて 極力避けるためである. 電動機の容量は $200 \mathrm{~V}, 50 \mathrm{~Hz}$, $65 \mathrm{~kW}$ で, 冷却方式は水循環冷却である. ガス処理量は 最大 $300 \mathrm{~N} \mathrm{~m}^{3} / \mathrm{h}$ である. 吐出圧は供給ガス量を自動弁 により調節することによつて変えられる.

\section{$2 \cdot 3$ ガスホルダ}

ガスホルダは容量 $1 \mathrm{~m}^{3}$ で, 水分などのガスの逆拡散 しない処理を施した鋼製である.閉ループの高圧側と低 圧側（圧縮機戻り）に接続された 2 個の自動弁により， 圧縮機の吸込み圧が $0.01 〜 0.02 \mathrm{~atm}$ になるよう調整さ れる. ガスホルダ内圧力は装置停止時約 $7 \mathrm{~atm}$ である が，装置のループ内が十分冷却された定常状態ではルー プ内のガス量が増えるため約 $3 \mathrm{~atm}$ に減少する.

\section{$2 \cdot 4$ 機外精製機}

冷凍機を長時間運転してもガスの流路が不純物の凍結 等により閉塞されるのを防止するため，あらかじめ閉儿 ープ内のーリウムガス中の不純物は十分除去されなけれ ばならない，精製機は水分除去用のモレキュラーシーブ 又吸着器と, 液体窒素温度で酸素・窒素を吸着させる活 性炭吸着器からなる．精製機により閉ループ内の水分は $10 \mathrm{ppm}$ 以下，酸素之窒素の合計濃度も $10 \mathrm{ppm}$ 以下之 なる. 装置の運転前に，系内の一部または全部のガスの 精製が行われる. 閉ループを開放しない限り, 運転ごと に精製を行ら必要はない。

\section{$2 \cdot 5$ ヘリウム冷凍機}

圧縮機から送られてきた高圧のヘリウムガスは冷凍機 
にはいり，第 1 から第 6 熱交換器と JT 熱交換器により 約 $5 \mathrm{~K}$ 李で泠却される. 第 8 熱交換器は冷凍機の断熱 シールドガス配管用の熱交換器で, 装置の起動時のみ用 いられる. 各熱交換器出口の温度等は Fig. 1 に示され ているが，第 1 熱交換器出口で約 $130 \mathrm{~K}^{3)}$ ，第 2 熱交換 器出口で約 $60 \mathrm{~K}$ である. 冷却されていくへリウムガス の一部は各段の膨張エンシンにはいり，断熱膨張により 第 1 段で約 $60 \mathrm{~K}$ ，第 2 段で約 $30 \mathrm{~K}$ そして第 3 段で約 8 K の寒冷を発生し低压ラインに戻る. JT 熱交換器を出 た高压へリウムガスは JT 弁で約 $0.1 \mathrm{~atm}$ まで自由断 熱膨張し, 温度降下により約 $50 \%$ の液体を含もミスト となる、へリウムミストは真空断熱されたミスト移送管 を通り, 疲れ試験機クライオスタット内の再凝縮器へ送 られる. ミストは再凝縮器で熱交換しガス化して冷凍機 に戻り，低圧ラインとして各熱交換器を通り圧縮機の吸 込み口に戻る。

この冷凍機の特徵は， 3 段膨張式のクロードサイクル で, 液体窒素等の外部寒冷括よび熱シールドを用いるこ となく寒冷を発生できる。冷凍能力は $4.4 \mathrm{~K}$ で約 $20 \mathrm{~W}$ である、膨張エンジンには 2 気筒往復動型を 2 台用い, 発電方式により動力を回収し，耐久性向上のため 150 r.p.m. の低速回転としている. 5 体の主熱交換器には アルミプレートフィン形熱交換器を採用し, 軽量化, 熱 効率の向上と流路閉塞の低減を図つている. JT 熱交換 器は無酸素銅の 2 重管形である. 冷凍機コールドボック ス内拈よびミスト移送管は真空断熱力式である. 冷凍機 内部の様子を Photo. 2 に示す. 下部に見觉るのが JT 熱交換器である。

\section{6 疲れ試験機}

試験機本体の荷重負荷装置は, 油压駆動, 荷重制御方 式で, 最大荷重動的 $\pm 5 \mathrm{t}$, 静的 $\pm 7.5 \mathrm{t}$ の引張圧縮の 両振り荷重が負荷できる. 試験周波数域は $0.01 \sim 50 \mathrm{~Hz}$ である。

Fig. 2 飞疲れ試験機クライオスタットの断面図を示 す. クライオスタットは真空積層断熱方式で, 液体窒素 の循環泠却方式を併用している. 試験中クライオスタッ トは完全に密閉すなわち封じきられ, 再凝縮器の働きに より内圧は約 $0.15 \mathrm{~atm}$ に保持される. 再凝縮器は液体 ヘリウム液面直上に設置され，材質は無酸素銅パイプ で, 伝熱効率向上のため三角錯列配置している.再凝縮 器において冷凍機から供給されたへリウムミストは, 再 凝縮器内外の温度差すなわちクライオスタット内のへリ ウムの蒸発量に応じて気化する。この潜熱により封じ切 られたクライオスタット内で蒸発したへリウムガスは再 液化され，液体へリウム液面は一定に保持される.

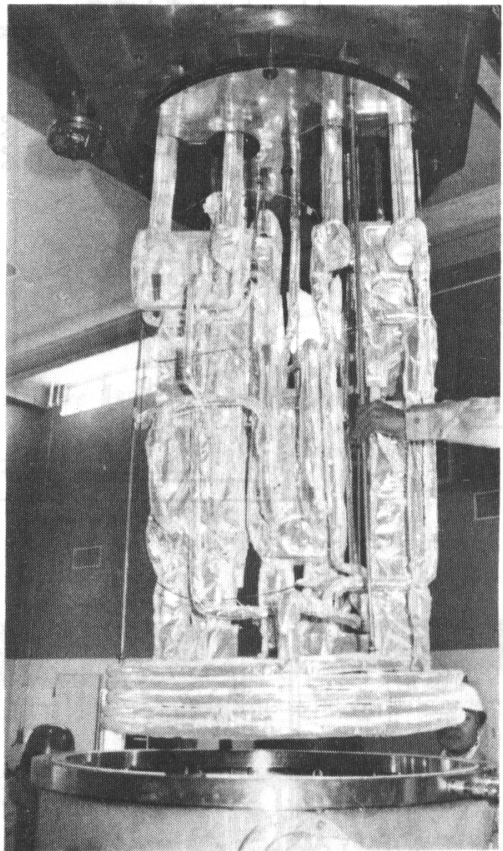

Photo. 2. Inner appearance of refrigerator.

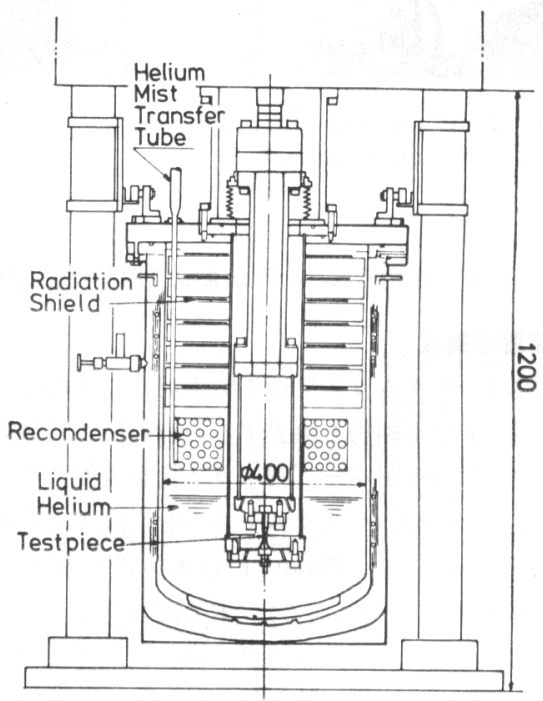

Fig. 2. Cryostat for fatigue testing apparatus.

試験片の形状を Fig. 3 に示す. 引張圧縮試験の際の 座屈を防ぐため, 中心部直径 $6 \mathrm{~mm}$ の砂時計形を採用 している、㨔具は二重円筒構造で, 固有振動数は試験機 との共振を回避するため $100 \mathrm{~Hz}$ 以上となつている.

Photo. 3 は試験片の交換のため試料筒を引き上げたと ころである。 


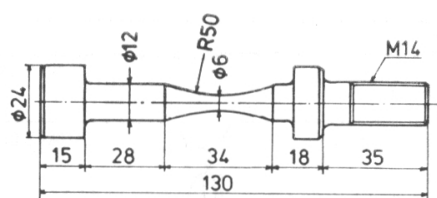

Fig. 3. Dimension of test specimens. (in $\mathrm{mm}$ )

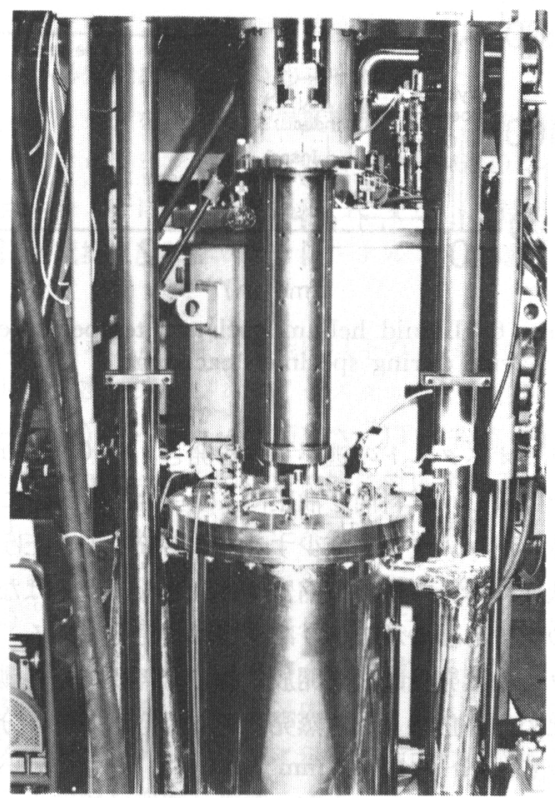

Photo. 3. Cryostat and cylinder for specimen holder.

\section{3. 冷却システムの運転}

\section{$3 \cdot 1$ 冷却時間の短縮}

本装置を起動し疲れ試験を開始するまでに, 圧縮機の 昇圧, 冷凍機扣よびクライオスタットの予冷, 膨張エン ジンによる冷却，JT 弁開度調節から液体へリウム注入 などの手順があり，毎々所定の時間を要する。 Fig. 4 は本装置が設置された昨年 3 月の冷却過程に括ける冷凍 機各部, 第 1 段膨張エンジン出, 第 3 膨張エンジン出, $\mathrm{JT}$ 弁入口求よび JT 熱交換器低圧側出の温度を時間の 経過で示したグラフである. 冷凍機内温度が定常状態に 達し, クライオスタット内の再凝縮器が有効飞働き, ク ライオスタットを封じ切れるようになるまで約 $17 \mathrm{~h} を$ 要していた。これは各熱交換器の熱容量が大きいことに もよるが，当初は急冷による熱応力の発生を極力避ける ため $1 \mathrm{~h} \mathrm{~K} 50^{\circ}$ 以上の急冷を行わず，委た冷却の手順 として各膨張エンジンを十分に働かせ内部を安定に冷却

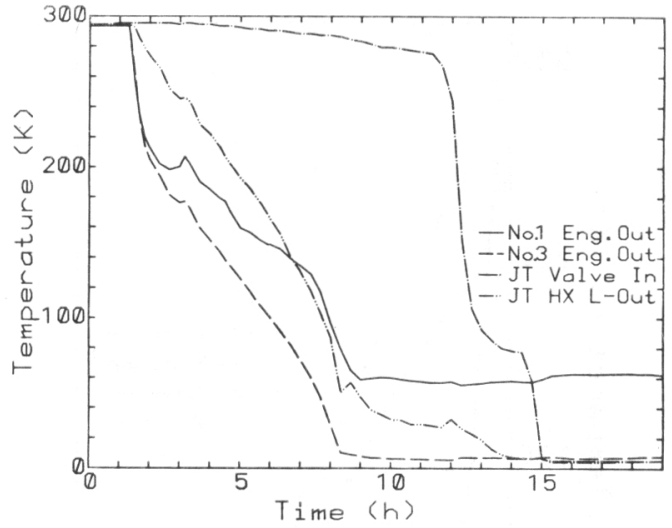

Fig. 4. Cooling behavior of refrigerator in March 1983.

した後, JT 熱交換器を冷却し十分な定常状態を得る力 針であつたことによる。このため第 1 と第 2 熱交換器に 備わつている予冷用の液体空素配管にも十分な液体空素 を流さなかつた。よつて温度変化は第 3 段膨張ェンジン 出の温度がまず降下した．次に JT 熱交換器の膨張エン ジン側までを十分冷却した後, クライオスタットに予冷 のための液体窒素を注入し，JT 弁を開き再凝縮器から の寒冷を利用し JT 熱交換器を冷却していた。このため ヘリウムミストが生成されるまで時間を要した。

装置の起動から疲れ試験開始まで半日以上を要してい たのでは運転時の労力の負担が大きすぎるため, 冷却時 間の短縮が求められた，現在の操作手順は, 装置の起動 直前にクライオスタットに予泠用の液体窒素を注入し, 第 1 打上び第 2 熱交換器にも予冷用の液体窒素を十分に 流しながら冷凍運転にはいる。熱交換器への液体爫素 は, 第 1 段膨張エンジン出の温度が液体窒素温度 $(77 \mathrm{~K})$ 付近に下がるまで約 $1 \mathrm{~h}$ 流される。一方 JT 弁を開き 液体空素につかつている再凝縮器からの寒冷に上り, 初 めから JT 熱交換器を冷却する. JT 熱交換器低圧側出 の温度が $77 \mathrm{~K}$ 付近に下がつた時点で, クライオスタッ 卜から液体窒素を完全に抜き液体へリウムを注入する. 液体へリウム液面が約 $200 \mathrm{~mm}$ に達するまで注入し, 冷凍機が定常状態になり液体へリウムの蒸発が落ち着い た後, 逃がし升を閉めクライオスタットを封じ切る. こ の上うに冷凍機の上部と下部から急冷したとさの冷凍機 各部の温度变化を Fig. 5 に示す. 装置の起動から封じ 切りまでの所要時間は約 $6 \mathrm{~h}$ であつた.

封じ切りを行うまでの液体窒素の所要量は約 $300 \mathrm{~kg}$ であり, 液体へリウムの所要量は約 $50 l$ である. 封じ 切り以後, 液体窒素はクライオスタットの冷却に $1 \mathrm{~h}$ 当 たり約 $15 \mathrm{~kg}$ 消費されるが，液体へリウムは補給する 


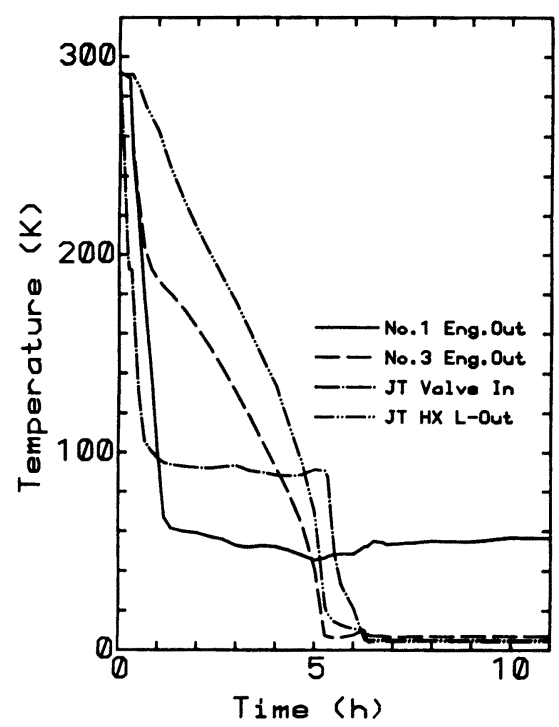

Fig. 5. Cooling behavior of refrigerator in May 1984.

必要はない.

\section{2 冷凍機連続運転中の試験片交換}

試験片が破断した後, 試験片を交換し次の試験を行う には, 従来は冷凍機を停止しクライオスタット内の液体 ヘリウムを蒸発させ, 内部を常温に戻す必要があつた. これは試料筒をクライオスタットに再び挿入する際の再 凝縮器への急激な熱侵入により, 冷凍機内の温度バラン スを崩してしまう懸念と, 水分の氷着などによりクライ オスタットの密封が不十分になる心配があつたことによ る.このため試験片を交換した後, 冷凍運転に入りクラ イオスタットを再び封じ切るをで, 初めの起動時と同じ 労力と時間を要し, クライオスタットの昇温時間と合わ せて非常に試験能率が悪い.

本装置の運転を繰り返し, 各部の操作および温度変化 を十分把握した上で, 冷凍機内の温度と圧力に注意しな がら, 再凝縮器を大気に開放した状態での試験片の交換 を試みた。 その結果クライオスタット内の再凝縮器に冷 凍機からの寒冷が供給されている状態で, 試料筒をクラ イオスタットから引き抜き試験片を交換し再度挿入して も, 冷凍機内温度の一部が上昇するが，温度バランスを 大きく崩すことはないことがわかつた，そして液体へリ ウムを補給し再度封じ切りをするまで, 約 $2 \mathrm{~h}$ で完了し た. Fig. 6 はこのときの液体へリウム液面の変化と冷 凍機内の各膨張エンジン出の温度, JT 弁入口, JT 熱交 換器低圧側入（ミスト移送管戻り）扎よび JT 熱交換器 低圧側出の温度変化を示したグラフである.

グラフ内にも記されているが試験片交換の手順は, ま

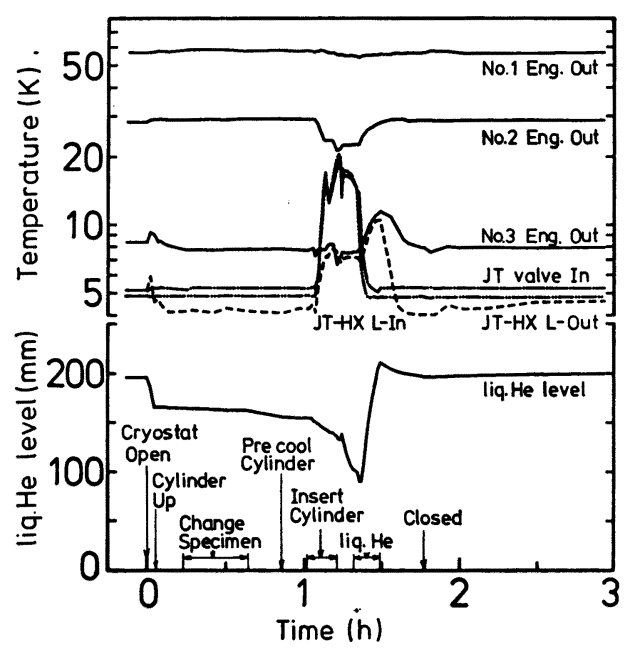

Fig. 6. Liquid helium level and temperature behavior during specimen exchange.

ずクライオスタットの逃がし弁を開き, 約 $0.15 \mathrm{~atm} の$ 内圧を開放し，試料筒を油圧により引き上げる．このと き液体へリウム液面は減少する. 試料筒を引き上げ大気 開放状態においても再凝縮器には大きな熱侵入はなく, 液面の減少も緩やかであり冷凍機は安定している. 液体 ヘリウムの蒸発量は大気開放状態でも再凝縮器が働いて いるため, 停止時（自然蒸発状態に対応）の約 3 分の 1 に減少し, $1 \mathrm{~h}$ あたり $3 \mathrm{~mm}$ (約 $0.4 l$ ) となつている. 試験片の固定に冷しばめを併用していることもあつて, 引き上げた試料筒を加熱し常温に戻した後試験片を交換 する. 試験片交換後, 試料筒に液体窒素を吹き付け予冷 する. 予冷を行わないと試料筒挿入時に液体へリウムの 蒸発量が多くほとんど蒸発してしまう。またミスト移送 管戻りの温度が著しく上昇し $50 \mathrm{~K}$ を越え, 冷涷機のバ ランスを崩す恐れがある，予冷後試料筒を液体へリウム の気化熱を利用しつつ静かに挿入する. ミスト移送管戻 りおよび JT 弁入口温度は約 $20 \mathrm{~K}$ まで上昇するが，挿 入完了とともに平常に戻る. 第 2 段膨張エンジン出の温 度が逆に下がつているのは, 温度上昇の影響を減らす目 的で JT 弁を絞つたため, 膨張ェンジンへの流量が増え て寒冷の発生量が増加したことによる．液体へリウム液 面は試料筒の挿入に伴い急激に減少するが，約半分は残 る. 蒸発した液体へリウム約 $15 l$ を補給し，各温度が 落ち着いた所でクライオスタットを封じ切り, 再び疲れ 試験を行う.

3.3 マイクロ・コンピュータを使つた温度監視システ

\section{ムの萛入}

本装置には各構成機器ごとに自動警報システムが設け 
られ，また圧縮機回りおよび冷凍機回りの温度を記録す るための多点温度記録計が備わつている. 一方, 系内の 冷却が完了し各温度が定常状態になるまでの起動時にお いては, 冷凍機内およびクライオスタット内の温度変化 に応じて, 装置各部の弁の開閉や流量調節その他の手順 を次々と進行させる．このため前述の冷却時間短縮など の作業の高能率化拉よび確実性の向上を四るには, 記録 計に依存するシステムでは不十分であり, 冷凍機の作動 状態および刻々と变化する温度を視覚的に表示するシス テムが必要である.この要求を満たすため，マイクロ・ コンピュータを使用した温度監視システムを導入した。

マイクロ・コンピュータは日立 MB-6890 レベル3， 多点スキャナには YHP 3497 A を用い, 温度センサに は白金抵抗温度計とクロメル・アルメル熱電対を使用し た。

このシステムの主な機能は以下のとおりである.

1) 冷凍機扣よびクライオスタット内の各部位の温度 （全 17 点）とへリウム液面高さ， JT 弁開度等を $15 \mathrm{~s}$ 間 隔でサンプリングし, 測定位置に対応する画面ディスプ レイ上に Fig. 1 のように表示する。 また温度域によつ て, 表示の色が変化する.

2）一定時間ごとまたは必要に応じて, 各温度・流量 等を印字扰よび磁気ディスクに記録する.

3) 運転状況に応じて系内のへリウムガスの流れる様 子を画面ディスプレイ上に示し，画面の動きを与えると ともに状況を把握しやすくする.

この温度監視シズテムの導入により, 冷却状況の微小 変化をも把握しやすくなり, 運転効率の向上に役立ち, さらに運転終了後に記録の再現をし冷却条件の十分な検 討が可能となつた.

\section{4 試験周波数の設定}

液体へリウム温度では，金属材料の比熱は常 温 の 約 1000 分の 1 になり, 熱云導率も常温の 10 分の 1 程度 になる.このため材料のわずかの変形によつても試験片 の温度は大きく上昇してしまい，一定の試験温度が保証 されない，一定の試験温度を確保するため, 試験中の試 験片の表面と中心部の温度を測定し試験周波数の上限を 求めた。チタン合金において得られた試験片中心部の温 度測定の結果を Fig. 7 に示す. 熱電対には Au-0.07\% $\mathrm{Fe}, \mathrm{Chromel}$ (線径 $0.2 \mathrm{~mm}$ ) を用い, 周囲の液体へリ ウムとの温度差により温度上昇を測定した．測定用の穴 の内径は $2 \mathrm{~mm}$, 深さ $87 \mathrm{~mm}$ で, 熱電対は試験片の鞍 部の中心に位置させた．四の横軸は試験周波数飞゙, 試験 応力は $111 \mathrm{kgf} / \mathrm{mm}^{2}$ である.この試料の降伏応力は $143 \mathrm{kgf} / \mathrm{mm}^{2}$ である.この試験応力では, 試験周波数が

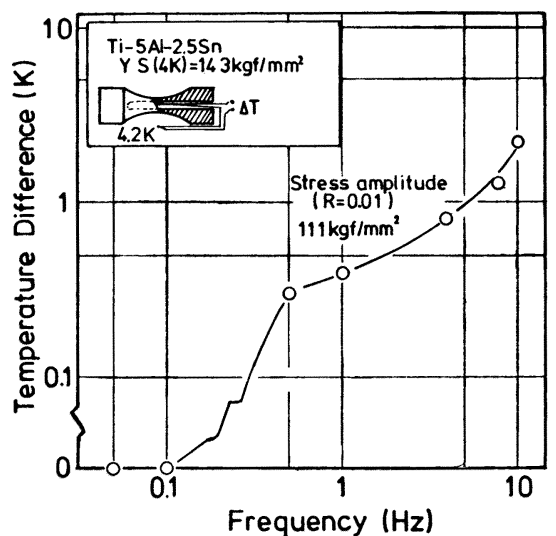

Fig. 7. Temperature rise as a function of frequncy and stress.

$5 \mathrm{~Hz}$ 以上になると 1 度以上の 温度上昇が生じている. 試験応力が小さくなれば試験片内部の温度上昇も減少す るが，試験周波数を統一するといら点から，チタン合金 における試験周波数を $4 \mathrm{~Hz}$ とした。な打この試験応力 では, 試験片表面の温度上昇はほぼ 0 であつた。

ステンレス鋼では降伏応力が低く, 塑性変形領域での 疲れ試験も行われるが，このときは発熱量が大きいた め, 試験周波数の上限は $1 \mathrm{~Hz}$ 程度と報告されている4).

\section{4. ま め}

極低温疲れ試験装置の導入により, 液体へリウムの補 給を必要とせずに，液体へリウム温度における材料の長 時間疲れ試験が可能になつた。これまでに行つてきた本 装置の運転の中で, およそ 1 週間にわたる疲れ破断試験 $\left(2 \times 10^{6}\right.$ サイクル) を行い直ちに試験片を交換し次の試 験をし, 再凝縮冷凍システムとしては最長 $460 \mathrm{~h}$ の連続 運転も達成している.

終わりに本装置の開発および運転に協力していただい た(株) 神戸製鋼所の佃渞二氏，大谷哲也氏，赤松正明 氏，新富正氏，福本昇氏他の方々に謝意を表します。

\section{交献}

1) Handbook on Materials for Superconducting Machinery (N. B. S.) sheet No. 8.1.3-4 (11/ 76) (1977) [Metals and Ceramics Information Center]

2 ) 小林俊一：低温技術 (1977), p. 24 [東京大学出 版会]

3 ）極低温における材料疲労に関する総合研究報告書 (1983), p. 44 [科学技術庁研究調整局]

4 ) $T$. Ohtani, $Y$. Ohtsu, $N$. Shiki, $Y$. Tomisaka, Y. Kawate, $Y$. Monju and $T$. Horiuchi: Proc. ICEC-9 (1982), p. 604 [Butterworths] 